\title{
Cd40-Cd40 Ligand System and P-selectin as Early Markers for Detection of Pre-eclampsia
}

\author{
SA Khodeer ${ }^{1}$, AM Abdu-Allah², WG El-Damaty ${ }^{3}$
}

\begin{abstract}
Objectives: Pre-eclampsia (PE) is a principal cause of maternal and fetal mortality and morbidity. The aim of this work was to assess the presence of inflammatory and thrombotic response during pre-eclampsia by demonstrating CD40-CD40 ligand and P-selectin in pre-eclamptic pregnant women.

Methods: The study included 81 pregnant women divided into three groups, Group I: 39 pregnant women with mild pre-eclampsia, Group II: 22 women with severe pre-eclampsia and Group III: 20 apparently healthy pregnant women. All Groups were subjected to complete clinical examination; prothrombin time and concentration, urea, creatinine, urinary protein, $C B C$, expression of CD40 on monocytes, $S C D 40 L$ and P-selectin.

Results: There was a statistically significant higher expression of CD40 on monocytes, $S C D 40 l L$ and $P$ selectin in the pregnant women with mild and severe pre-eclampsia compared with normotensive pregnant women $(\mathrm{p}<0.001)$. The most sensitive marker was $S C D 40 L$ while the highest specificity was the expression of CD40 on monocytes.

Conclusion: The study shows presence of activation of the CD40-CD40L system and elevated levels of $P$-selectin in women with pre-eclampsia - whether mild or severe types. Using of such markers may be essential for developing better prediction polices as well as for affecting patient treatment decisions forward and improving patient outcome for both babies and mothers suffering from pre-eclampsia.
\end{abstract}

Keywords: Inflammatory, preeclampsia, pregnant, p-selectin, mortality

\section{EI Sistema Ligando Cd40-Cd40 y la Selectina P como Marcadores Tempranos para la Detección de la Pre-eclampsia}

\author{
SA Khodeer ${ }^{1}$, AM Abdu-Allah², WG El-Damaty ${ }^{3}$
}

\begin{abstract}
RESUMEN
Objetivos: La pre-eclampsia es la principal causa de mortalidad y morbilidad materna y fetal. El objetivo de este trabajo fue evaluar la presencia de una respuesta inflamatoria y trombótica durante la preeclampsia mediante la demostración del ligando o mecanismo de acoplamiento CD40-CD40 y la selectina $P$ en las mujeres embarazadas pre-eclámpticas.

Métodos: El estudio incluyó 81 mujeres embarazadas divididas en tres grupos: Grupo I: 39 mujeres embarazadas con pre-eclampsia leve; Grupo II: 22 mujeres con pre-eclampsia grave; y Grupo III: $20 \mathrm{em}$ barazadas evidentemente sanas. Todos los grupos fueron sometidos a examen clínico completo, tiempo y concentración de protrombina, urea, creatinina, proteinas urinarias, CBC, expresión de CD40 en monocitos, $s C D 40 L$ y selectina $P$ fueron evaluados.

Resultados: Hubo una expresión mayor estadísticamente significativa de CD40 en monocitos, sCD40lL y selectina $P$ en las mujeres embarazadas con pre-eclampsia leve y grave, en comparación con las mujeres embarazadas normotensas $(\mathrm{p}<0.001)$. El marcador más sensible fue $S C D 40 L$, mientras que la especificidad más alta fue la expresión de CD40 en monocitos.

Conclusión: El estudio muestra la presencia de activación del sistema CD40-CD40L y el nivel elevado de selectina P en las mujeres con pre-eclampsia, ya sean los tipos leves o severos. El uso de estos mar-
\end{abstract}

From: ${ }^{1}$ Department of Clinical Pathology, Faculty of Medicine, Menofiya University, Shebein El-Kom, Egypt ${ }^{2}$ Department of Medical Biochemistry, Faculty of Medicine, Taibah University, KSA and Menofiya University, Egypt and ${ }^{3}$ Department of Obstetrics and Gynecology, Faculty of Medicine, Menofiya University, Shebein El-Kom, Egypt.
Correspondence: Dr AM Abdu-Allah, Department of Medical Biochemistry, Faculty of Medicine, Taibah University, Al Madinah, KSA. E-mail: azza.abdallah@yahoo.com 
cadores puede ser esencial para desarrollar mejores políticas predicción, modificar la decisión de tratamiento del paciente a la hora de seguir adelante, y mejorar los resultados de los pacientes, tanto para los bebés como para las madres que sufren de preeclampsia.

Palabras claves: Inflamatoria, pre-eclampsia, embarazada, selectina P, mortalidad

West Indian Med J 2016; 65 (3): 462

\section{INTRODUCTION}

Pre-eclampsia is a principal cause of maternal and fetal mortality and morbidity. It is associated with an increase in maternal blood pressure and deterioration of renal function, intrauterine growth retardation, persistent immune activation and multi-organ dysfunction $(1,2)$. The prevalence of preeclampsia ranges between $2-10 \%$ of pregnancies so, its incidence varies worldwide. World health organization estimates the occurrence of pre-eclampsia to be seven times higher in developing countries ( $2.8 \%$ of live births) than in developed countries [0.4\%], (3).

Early-onset pre-eclampsia occurs within 34-weeks of pregnancy. Despite ensuring maternal safety, the only treatment for PE is early pregnancy termination, as PE often results in serious neonatal developmental complications. For that reason, prevention and early discovery from PE is crucial (4). The principal mechanisms responsible for the pathogenesis of preeclampsia are inadequately understood (5). Even though the cause of pre-eclampsia is unknown, endothelial cell dysfunction plays an important part in its pathogenesis (4).

The CD40L is a trimeric, trans-membrane protein of the tumour necrosis factor family and, together with its receptor $\mathrm{CD} 40$, plays an important role in the inflammatory processes that cause atherosclerosis and thrombosis (6). The CD40CD40L system is extensively distributed in a variety of cells, including leukocytic, and non-leukocytic, endothelial and smooth muscle cells (7) and on activated platelets (6). It also occurs in a soluble form that is fully active biologically, termed soluble CD40 ligand (sCD40L), which is shed from stimulated lymphocytes and is actively released after platelet stimulation (8). Soluble sCD40L is pro-inflammatory for endothelial cells and provoke coagulation by stimulating expression of tissue factor on monocytes.

$\mathrm{P}$-selectin, which is a $140 \mathrm{kD}$ protein is present in the alpha granules of platelets and the Weibel-Palade bodies of endothelial cells. It is one of the selectin family of adhesion molecules, which take part in reproduction and haemostasis (10-12). During pregnancy, maternal P-selectin expression occurs entirely at the implantation site and permit the mechanism for maternal and fetal cell interaction to give a chance to the trophoblast to implant itself within the uteroplacental vessel lumen (13). P-selectin is secreted from the cell surface and circulates as a soluble molecule in the plasma (14). Both the membrane and the soluble form of P-selectin are agonists of the processes of thrombosis and inflammation (15). Moreover, P-selectin could support platelet-platelet interactions and play an important role in the early stages of inflammation, throm- bosis and atherosclerosis by promoting plaque formation and progression (15).

This work was done to assess the presence of inflammatory and thrombotic response during pre-eclampsia by demonstrating CD40-CD40 Ligand and P-selectin in pre-eclamptic pregnancies compared with normal pregnancies and how it could be used as markers for early detection of pre-eclampsia.

\section{SUBJECTS AND METHODS}

This study was carried out at the Clinical Pathology Department in collaboration with Medical Biochemistry and Obstetrics and Gynecology Departments, Menoufiya University Hospitals, Faculty of Medicine, in the duration between March 2010 and December 2013.

Subjects: the study included 81 pregnant women from those attending the Outpatient Clinic and Inpatient Department of Menoufiya University Hospitals. According to the clinical examination, laboratory findings, subjects sharing in this study were classified into three groups as follows: Group I: Consisted of 39 pregnant females suffering from mild pre-eclampsia at gestational age after 20 weeks of pregnancy whose age-range from 25-33 years old: Group II: Consisted of 22 pregnant females suffering from severe pre-eclampsia at gestational age after 20 weeks of pregnancy and whose ages ranged from 25-33 years old and Group III: Consisted of 20 apparently healthy pregnant females, at gestational age after 20 weeks of pregnancy whose ages ranged from 25-30 years old.

*Exclusion criteria: Women with and without pre-eclampsia with a history of hypertension, hepatic or renal disease, cardiac disease, diabetes mellitus, established atherosclerosis, malignancy, autoimmune disease, systemic infection, recent major surgery or trauma, alcohol consumption and cigarette smoking.

*Inclusion criteria: patients with pre-eclampsia in Groups I and II and normal pregnant women in Group III; gestational age corroborated by ultrasound after 20 weeks; a singleton fetus and no fetal structural anomaly.

Blood samples were collected before the administration of any ante-partum treatment agents.

The study design was accepted by the local Ethics Committee. Informed consents were obtained from the shared women.

Methods: All subjects included in this study were subjected to the following: Thorough history taking and complete clinical examination, prothrombin time and concentration, urea, crea- 
tinine, urinary protein, $\mathrm{CBC}$, expression of CD40 on monocytes, sCD40L and P-selectin.

\section{A-Sample collection}

Blood samples: Venous blood samples were collected from each woman under complete aseptic condition by sterile vein puncture without venous stasis. Each sample was divided as follows: $4 \mathrm{~mL}$ of blood were allowed to clot at $37^{\circ} \mathrm{C}$, serum was separated by centrifugation and used for immediate assay of kidney and liver function tests. The remaining portion was divided into two aliquots and kept at $-80^{\circ} \mathrm{C}$ until testing for assaying of sCD40L and P-selectin. One $\mathrm{mL}$ of blood was added to a EDTA-contained sterile tube for platelet count, $1.8 \mathrm{~mL}$ of blood was added to a citrated tube for estimation of prothrombin time and concentration and $2 \mathrm{~mL}$ of blood were added to a citrated tube, the citrated blood was fixed immediately by adding $1 \%$ formaldehyde (1:1) for determination of CD40 expression on monocytes .

Urine sample: Twenty-four-hour urine was collected from each woman for estimation of total protein in urine.

\section{B) Analytical Methods}

1. Biochemical tests for detection of urea, creatinine, ALT, AST were done on SYNCHIRON CX9 auto analyser using a kit supplied by Beckman (BacKman, Instrument. Inc., Scientific Instrument Division, Fullerton, CA92634-3100. USA).

2. Determination of $\mathbf{S C D} 40 \mathrm{~L}$ concentrations: A sandwich enzyme immunoassay test kit (Quantikine, Human soluble CD40 Ligand Immunoassay R\&D system, USA) was used for the quantitative determination of soluble CD40L. A polyclonal antibody specific for CD40 L was pre-coated onto a microplate. Standards and samples are pipetted into the wells and any CD40 Ligand present was bound by the immobilized antibody. After washing away any unbound substances, an enzyme-linked polyclonal antibody specific for CD40 Ligand was added to the wells. Following a wash to remove any unbound antibody-enzyme reagent, a substrate solution was added to the wells and colour changes developed in proportion to the amount of CD40 Ligand bound in the initial step. The colour development is stopped and the intensity of the colour was measured at $450 \mathrm{~nm}$ using an ELISA reader. The concentrations of sCD40L were read from the standard calibration curve.

3. Soluble P-selectin: This was determined using a sandwich ELISA assay (human sP-selectin sandwich ELISA kit, Invitrogen Corporation Camarillo. www.invitrogen.com). An antisP-selectin monoclonal coating antibody was adsorbed onto microwells. sP-selectin present in the sample or standard, bound to antibodies adsorbed to the microwells; an HRP-conjugated monoclonal anti-sP-selectin antibody was added and bound to sP-selectin captured by the first antibody. Following incubation, unbound enzyme conjugated with anti-sPselectin was removed during a wash step and substrate solution reactive with HRP was added to the wells. A coloured product was formed in proportion to the amount of soluble sP-selectin present in the sample or standard. The reaction is terminated by addition of acid and absorbance was measured at $450 \mathrm{~nm}$. 4. Flow cytometric analysis for determination of CD40 on monocytes: (FACS Calibur cytometer; Becton Dickinson, USA): fixed blood was diluted 1:5 and incubated with FITCconjugated anti-CD40 and anti-CD14 phycoerythrin for 30 minutes at room temperature. Erythrocytes were removed by adding $2 \mathrm{~mL}$ of FACS lysis solution for 10 minutes at room temperature. Leucocytes were washed twice with PBS and fixed in 1\% formaldehyde in PBs. Monocytes were identified by gating for $\mathrm{CD} 14^{+}$cells. The results were presented as mean fluorescent intensity (MFI).

\section{Statistical analysis}

The statistical analysis was undertaken using SPSS software (version 17; SPSS Inc, Chicago, IL, USA). Descriptive statistics in the form of mean and standard deviation for parametric data were used. Analysis of variance test for comparison between the three groups having quantitative variables normally distributed and Kruskal-Wallis test for comparison between three groups not normally distributed having quantitative variables followed by least significant difference (LSD). The significant level was set at 0.05 or less. Spearman correlation test was used to measure the association between two parametric quantitative variables. The receiver operating characteristic curve is a graphic representation of the relationship between sensitivity and specificity at different cut-off points for a diagnostic test.

\section{RESULTS}

The details of clinical characteristics and laboratory findings in patients' groups and normal pregnant women are listed in (Table1). There were no statistical significant differences between the women with mild and severe pre-eclampsia and the normotensive pregnant women regarding maternal age, or gestational age at blood sampling. Blood pressure was significantly higher in the women with mild and severe pre-eclampsia compared with the normotensive pregnant women. There were significant decrease in platelet count and albumin concentration and significant increase in creatinine and urea in women with mild and severe pre-eclampsia compared with the normal pregnancy group. The expression of CD40 on monocytes and the serum concentration of sCD40L showed statistically significant increase in both groups of pre-eclampsia patients compared with normal pregnant women. Meanwhile, no statistically significant difference was observed between the studied groups of mild and severe pre-eclampsia. Regarding P-selectin, the highest level was recorded by the group of severe pre-eclampsia followed by group of mild pre-eclampsia and lastly the group of normal pregnant women.

There were statistically significant differences between both groups of women with pre-eclampsia and normal pregnant women, but no statistically significant difference was found between women in the mild and severe pre-eclamptic groups. Spearman correlation showed positive significant 
Table 1: Statistical comparison of the clinical and laboratory characteristics of the studied groups

\begin{tabular}{|c|c|c|c|c|c|}
\hline Variable & $\begin{array}{c}\text { Normal } \\
\text { pregnant } \\
\mathbf{n}=\mathbf{2 0}\end{array}$ & $\begin{array}{l}\text { Mild pre-eclampsia } \\
\quad \mathbf{n}=\mathbf{3 9}\end{array}$ & $\begin{array}{c}\text { Severe } \\
\text { pre-eclampsia } \\
\mathbf{n}=\mathbf{2 2}\end{array}$ & F test & $p$-value \\
\hline Age (years) $\mathrm{X} \pm \mathrm{SD}$ & $27.55 \pm 1.70$ & $27.43 \pm 1.76$ & $27.59 \pm 1.7$ & 0.06 & $>0.05$ \\
\hline $\begin{array}{l}\text { Gestational age at sampling (weeks) } \\
X \pm \text { SD }\end{array}$ & $31.20 \pm 1.28$ & $33.97 \pm 0.90$ & $34.0 \pm 0.93$ & 56.8 & $<0.001$ \\
\hline Systole $(\mathrm{mm} / \mathrm{Hg})$ & & & & 22.3 & $<0.001^{1}$ \\
\hline $\mathrm{X} \pm \mathrm{SD}$ & $115.0 \pm 4.59$ & $145.13 \pm 5.06$ & $167.95 \pm 5.04$ & $\begin{array}{l}35.5 \\
16.9\end{array}$ & $<0.001^{2}$ \\
\hline Diastole (mm/Hg) & $74.0 \pm 5.02$ & $99.49 \pm 4.10$ & $105.0 \pm 5.12$ & $\begin{array}{c}19.58 \\
19.8 \\
4.3\end{array}$ & $\begin{array}{l}<0.001^{1} \\
<0.001^{2}\end{array}$ \\
\hline SGOT (U/L) & & & & 0.44 & $0.66^{1}$ \\
\hline $\mathrm{X} \pm \mathrm{SD}$ & $30.2 \pm 3.29$ & $29.82 \pm 3.04$ & $30.0 \pm 2.81$ & $\begin{array}{l}0.21 \\
0.23\end{array}$ & $\begin{array}{l}0.83^{2} \\
0.82^{3}\end{array}$ \\
\hline SGPT (U/L) & & & & 0.001 & $0.99^{1}$ \\
\hline $\mathrm{X} \pm \mathrm{SD}$ & $30.05 \pm 3.36$ & $30.05 \pm 3.40$ & $29.64 \pm 3.44$ & $\begin{array}{l}0.39 \\
0.45\end{array}$ & $\begin{array}{l}0.70^{2} \\
0.65^{3}\end{array}$ \\
\hline Albumin (gm/dL) & & & & 14.05 & $<0.001^{1}$ \\
\hline $\mathrm{X} \pm \mathrm{SD}$ & $3.85 \pm 0.22$ & $2.79 \pm 0.29$ & $2.83 \pm 0.31$ & 12.3 & $<0.001^{2}$ \\
\hline Range & & & & 0.40 & $0.69^{3}$ \\
\hline Prothrombin conc. (\%) & & & & 4.68 & $<0.001^{1}$ \\
\hline $\mathrm{X} \pm \mathrm{S}$ & $92.4 \pm 5.9$ & $85.82 \pm 2$ & $85.68 \pm 3$ & $\begin{array}{l}4.5 \\
0.17\end{array}$ & $\begin{array}{c}<0.001^{2} \\
0.86^{3}\end{array}$ \\
\hline Urea $(\mathrm{mg} / \mathrm{dL})$ & & & & 7.36 & $<0.001^{1}$ \\
\hline $\mathrm{X} \pm \mathrm{SD}$ & $38.15 \pm 1.81$ & $42.23 \pm 2.11$ & $42.5 \pm 2.15$ & $\begin{array}{l}7.0 \\
0.47\end{array}$ & $\begin{array}{c}<0.001^{2} \\
0.643\end{array}$ \\
\hline Creatinine $(\mathrm{mg} / \mathrm{dL})$ & & & & 5.66 & $<0.001^{1}$ \\
\hline $\mathrm{X} \pm \mathrm{SD}$ & $0.79 \pm 0.19$ & $1.14 \pm 0.29$ & $1.16 \pm 0.28$ & $\begin{array}{l}5.10 \\
0.24\end{array}$ & $\begin{array}{c}<0.001^{2} \\
0.81^{3}\end{array}$ \\
\hline Protein in 24-hour urine (mg/24h) & & & & 18.01 & $<0.001^{1}$ \\
\hline $\mathrm{X} \pm \mathrm{SD}$ & & & & 13.7 & $<0.001^{2}$ \\
\hline & $120.5 \pm 40.06$ & $606.92 \pm 159.1$ & $610.45 \pm 162.49$ & 0.08 & $0.93^{3}$ \\
\hline Platelets $\left(\times 10^{3}\right)$ & & & & 2.72 & $0.009^{1}$ \\
\hline $\mathrm{X} \pm \mathrm{SD}$ & $180.0 \pm 16.22$ & $161.79 \pm 35.1$ & $167.05 \pm 34.25$ & $\begin{array}{l}1.59 \\
0.57\end{array}$ & $\begin{array}{l}0.12^{2} \\
0.57^{3}\end{array}$ \\
\hline
\end{tabular}

Table 2: Comparison between the studied groups as regard sCD40L, CD40 on monocytes and P-selectin

\begin{tabular}{|c|c|c|c|c|c|}
\hline \multirow[b]{2}{*}{ Variable } & \multicolumn{2}{|c|}{ Studied groups } & \multirow[b]{2}{*}{$\begin{array}{c}\text { Severe } \\
\text { pre-eclampsia } \\
\mathbf{n}=\mathbf{2 2}\end{array}$} & \multirow{2}{*}{$\begin{array}{c}\text { Mann } \\
\text { Whitney }\end{array}$} & \multirow{2}{*}{$\begin{array}{c}p \\
\text { value }\end{array}$} \\
\hline & $\begin{array}{l}\text { Normal } \\
\text { pregnant } \\
\mathbf{n}=\mathbf{2 0}\end{array}$ & $\begin{array}{c}\text { Mild } \\
\text { pre-eclampsia } \\
\mathbf{n}=\mathbf{3 9}\end{array}$ & & & \\
\hline $\mathrm{sCD} 40 \mathrm{~L}(\mathrm{ng} / \mathrm{mL})$ & & & & 6.2 & \\
\hline $\mathrm{X} \pm \mathrm{SD}$ & $0.33 \pm 0.11$ & $1.71 \pm 1.88$ & $1.75 \pm 0.89$ & $\begin{array}{l}5.5 \\
1.26\end{array}$ & $\begin{array}{r}<0.001 \\
<0.002 \\
0.213\end{array}$ \\
\hline $\begin{array}{l}\mathrm{CD} 40 \text { expression on } \\
\text { monocytes (FMI) } \\
\mathrm{X} \pm \mathrm{SD}\end{array}$ & $5.92 \pm 2.14$ & $22.42 \pm 4.99$ & $20.43 \pm 6.95$ & $\begin{array}{l}6.3 \\
4.4 \\
0.80\end{array}$ & $\begin{aligned} &<0.001^{1} \\
&<0.051^{1} \\
& 0.43^{3}\end{aligned}$ \\
\hline $\begin{array}{l}\text { P-selectin } \quad(\mathrm{ng} / \mathrm{mL}) \\
\mathrm{X} \pm \mathrm{SD}\end{array}$ & $137.65 \pm 54.29$ & $251.18 \pm 79.76$ & $284.56 \pm 46.02$ & $\begin{array}{l}4.2 \\
6.0 \\
1.19\end{array}$ & $\begin{array}{l}0.001^{1} \\
0.001^{2} \\
0.23^{3}\end{array}$ \\
\hline
\end{tabular}

$1=$ Comparison between group of pregnant women with mild pre-eclampsia and group of women with normal pregnancy.

2 = Comparison between group of pregnant women with mild pre-eclampsia and group of women with normal pregnancy.

$3=$-comparison between groups of pregnant women of mild and severe pre-eclampsia 
Table 3: Presentation of data extracted from the ROC curve of $\mathrm{sCD} 40 \mathrm{~L}$ in serum, CD40 expression in monocytes and P-selectin for detection of preeclampsia

\begin{tabular}{llll}
\hline & $\begin{array}{c}\text { CD40 ligand in } \\
\text { serum }\end{array}$ & $\begin{array}{c}\text { CD40 in } \\
\text { monocytes }\end{array}$ & P selectin \\
\hline AUC & 0.998 & 0.97 & 0.94 \\
P value & $<0.001$ & $<0.001$ & $<0.001$ \\
$95 \%$ CI & $0.99-1$ & $0.93-1.01$ & $0.89-0.99$ \\
Cutoff point & 0.575 & 12 & 203 \\
Sensitivity & 100 & 96.7 & 88.5 \\
Specificity & 95 & 100 & 85 \\
PPV & 98.4 & 100 & 95.2 \\
NPV & 100 & 90.9 & 89.5 \\
\hline
\end{tabular}

\section{$r=+0.59 \quad P$ value $<0.001$}

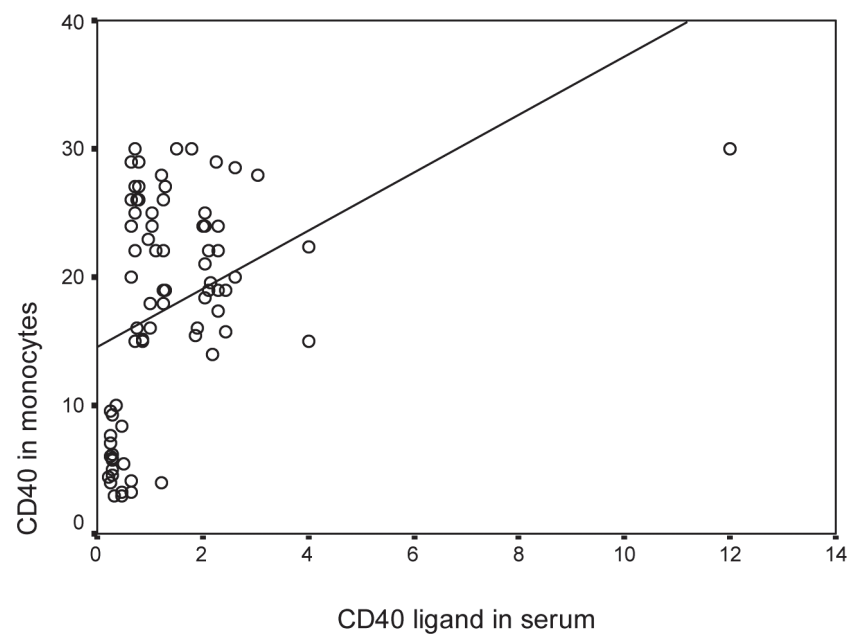

Fig. 1: Spearman correlation between Scd40L and CD40 expression on monocytes in the studied group.

$$
r=+0.46 \quad P \text { value }<0.001
$$

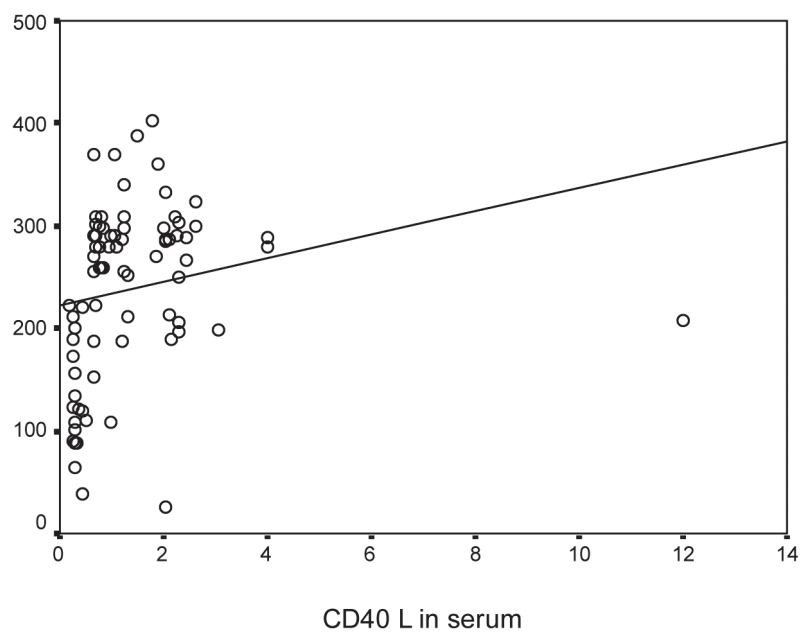

Fig. 2: Spearman correlation between $\mathrm{SCD} 40 \mathrm{~L}$ and P-selectin in the studied group.

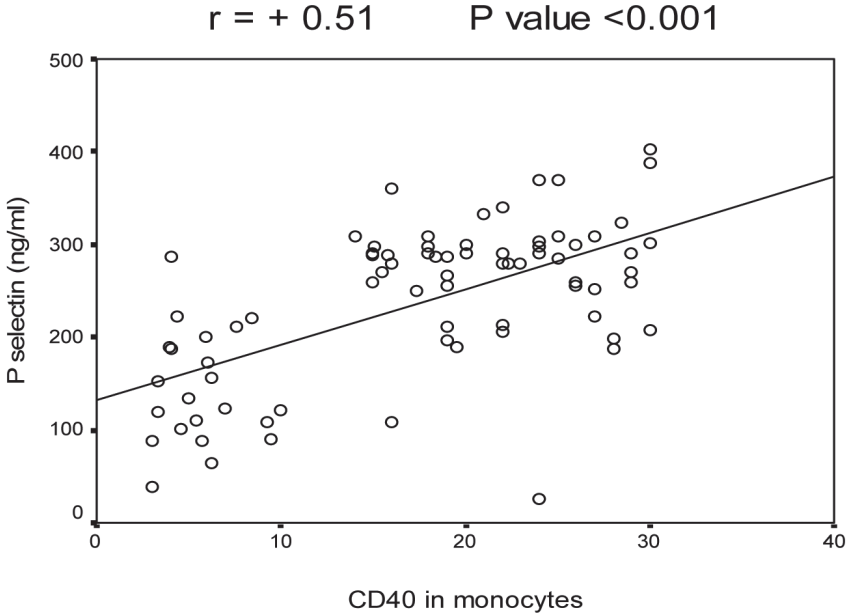

Fig. 3: Spearman correlation between P-selectin and CD40 expression on monocytes in the studied groups.

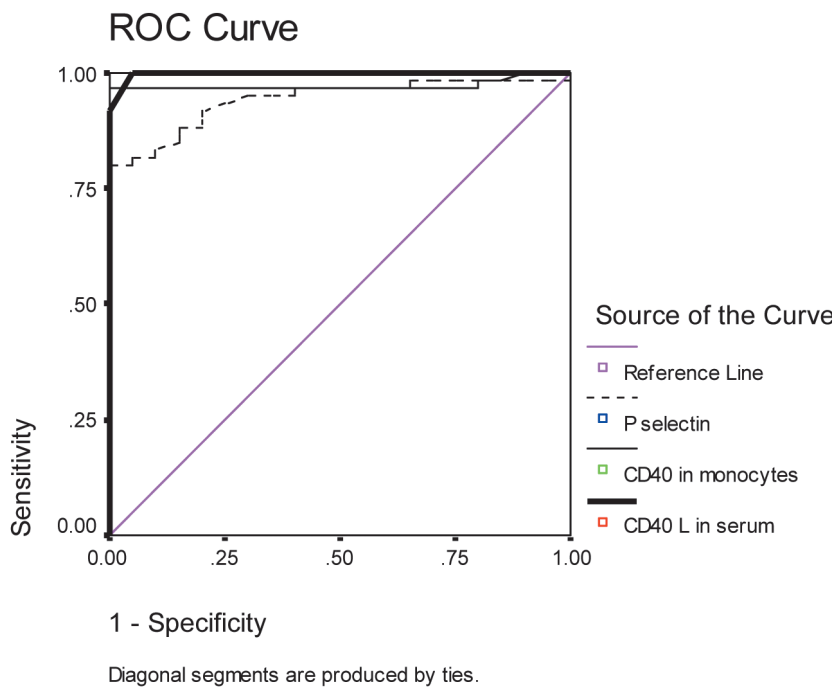

Fig. 4: The ROC curve of $\mathrm{sCD} 40 \mathrm{~L}$ in serum, CD40 expression in monocytes and P-selectin for detection of pre-eclampsia.

correlation between $\mathrm{SCD} 40 \mathrm{~L}$ in serum, CD40 expression on monocytes and P-selectin in the whole studied groups. By using ROC curve for CD40 expression on monocytes, the best cutoff level was 12 foundation medicine reports with a sensitivity of $96.7 \%$, specificity $100 \%$, PPV $100 \%$, NPV $90.9 \%$. Meanwhile, the best cutoff level for sCD40L was $0.57 \mathrm{ng} / \mathrm{mL}$ with a sensitivity of $100 \%$, specificity $95 \%$, PPV $98.4 \%$, NPV $100 \%$. Moreover, the best cutoff level of P-selectin was 203 $\mathrm{ng} / \mathrm{mL}$ with a sensitivity of $88.5 \%$, specificity $85 \%$, PPV 95.2\%, NPV 89.5.

\section{DISCUSSION}

Pre-eclampsia has been studied extensively because of its involvement with high maternal and fetal morbidity. The pathogenesis of pre-eclampsia is not obviously understood. Roberts et al (16), reported maternal endothelial dysfunction with pre- 
eclampsia. Also, Bar et al (17), found that platelet activation, platelet aggregation and progressive damage to endothelial cells were all characteristics of pre-eclampsia. The relationship between the exaggerated platelet activation and inflammation leading to endothelial damage in pre-eclampsia can be explained by the described CD40-CD40L system (18).

In the current work, the mean level of P-selectin was found to be statistically higher not only in women with mild pre-eclampsia compared with the control group, but also in women with severe pre-eclampsia compared with women with normal pregnancy. In addition, the mean level of p-selectin is higher in women with severe pre-eclampsia than in mild preeclamsia but this difference did not reach a statistically significant level. Yoneyama et al (19), presented a significantly higher expression of P-selectin in pre-eclampsia than in apparently healthy pregnant women.

Similar results of increased levels of sP-selectin in preeclamptic pregnancies were obtained by Halim et al (20) and Chaiworapongsa et al (21). Furthermore, Bosio et al (22) found higher levels of sP-selectin in pre-eclampsia but levels of soluble P-selectin were not significantly increased in women with pregnancy induced hypertension without proteinuria. Also, they proposed that their findings support an inflammatory model for pre-eclampsia, while the endothelial cell activation might be secondary to a primary inflammatory response. However, Karalis (23) observed significantly increased levels of both P-selectin and its soluble form in women with pregnancy-induced hypertension in comparison with pregnant women with normal blood pressure and normal pregnancy is connected with increased platelet activation followed by further alteration in these parameters in pregnancies complicated by hypertension. In contrast to our results, Heyl et al (24), found levels of P-selectin in hypertensive patients similar to those found in healthy controls.

Also, our findings were in accordance with the results reported by Laskowska et al (25), who suggest that the elevated level of the soluble P-selectin is associated with preeclampsia. sP-selectin acts as a marker for platelet and endothelial activation and as an initiator of the procoagulant state, as well as playing an important role in atherosclerosis. Our results of elevated sP-selectin in pre-eclampsia seem to confirm that these processes occur in pre-eclamptic pregnant women and the excess circulating sP-selectin aid in the pathogenesis of this pregnancy-specific disorder.

In the present study, the expression of CD40 on monocytes and SCD40L were significantly higher in women with mild and severe pre-eclampsia compared with normal pregnant women. Meanwhile, no statistically significant differences were found between both groups of women with pre-eclampsia regarding the expression of $\mathrm{CD} 40$ on monocytes and $\mathrm{SCD} 40 \mathrm{~L}$. These findings were unexpected but this may be explained by the smaller number of women with severe preeclampsia

Engagement of CD40 on monocytes induces many procoagulant and pro-inflammatory effects (26). CD40 on mono- cytes might be upregulated by pro-inflammatory mediators, such as C-reactive protein (CRP) (27). CRP has been found to be elevated in pre-eclampsia (28). CD40 engagement on monocytes might also occur through enhanced interaction between platelets and monocytes, because monocytes rapidly adhere for prolonged periods to activated platelets that display p-selectin (29). This enhanced interaction between platelets and monocytes, through the engagement of CD40, increases the release of pro-inflammatory and pro-thrombotic factors. Thus, the link between the exaggerated platelet activation and inflammation leading to endothelial dysfunction and damage in pre-eclampsia may be explained by the persistent upregulation of the CD40-CD40L system and the mediatory role of CD40L.

In accordance with our results, Mellembakken et al (30) observed increasing the concentrations of SCD40L in plasma of patients with pre-eclampsia containing platelets in comparison to plasma deprived of thrombocytes. They suggested that enhanced platelet activation during preeclampsia might result in increased secretion of inflammatory factors, possibly leading to inflammation, leukocyte stimulation and endothelial malfunction.

Also, our results agreed with the results of a study done by Oron et al (31) who reported that the mean levels of sCD40L were significantly different among the studied groups. The highest levels were detected in the non-pregnant women and the pre-eclamptic women and the lowest level was found in the normal pregnant women.

Moreover, the obtained results agreed with those done by Darmochwal-Kolarz et al (32), who studied the concentration of the inflammatory markers CD40L and SCD40L in normal pregnancy and pre-eclampsia. In the group of patients with pre-eclampsia, they observed significantly higher serum concentrations of $\mathrm{sCD} 40 \mathrm{~L}$ than in the normal third trimester. They found significantly lower concentrations of SCD40L all over the trimesters of normal pregnancy than in healthy nonpregnant women. Lower concentrations of SCD40L may suggest decreased CD40-CD40L interactions of $\mathrm{CD}^{+}$ tlymphocytes with antigen-presenting cells and decreased activation of innate immunity during normal pregnancy. This might be one of the mechanisms protecting the developing fetus against the activation of the maternal immune system. A study done by Lukanov et al (33) reported that there was a significantly higher expression of CD40 and CD40L on platelets and CD40 on monocytes in the women with pre-eclampsia compared with normotensive pregnant women. The serum concentration of sCD40L was significantly higher in women with pre-eclampsia compared with normotensive pregnant women. In a study done by Lukanov et al (34) it was reported that the preeclamptic women showed a significant increase in CD40L and in CD40 on monocytes when compared with normotensive pregnant women and non-pregnant women.

Recently, a study done by Azam et al (35) demonestrated that expression of CD40L was significantly higher in women with mild and severe pre-eclampsia compared with the normal pregnancy group $(p=0.001 ; p \leq 0.001 ; p=0.003$, respec- 
tively). However, whether sCD40L can elicit an inflammatory response remains controversial. Henn et al (8) and Laskowska et al (36) found that even high-levels of SCD40L failed to induce an inflammatory reaction. They concluded that the CD40-CD40 L interaction leads, over time, to the transformation of CD40L to the biologically inactive $\mathrm{SCD} 40 \mathrm{~L}$, thereby effectively limiting the inflammatory process in the vascular system, and protecting maternal immune cells bearing CD40 receptors from Fas-mediated apoptosis.

By using the ROC curve for comparison between the three studied markers, the highest sensitivity belonged to sCD40L, followed by CD40 expression on monocytes and lastly P-selectin regarding the specificity, the highest specificity was a share of CD40 expression on monocytes then sCD4 40L then P-selectin. It could be concluded that the present study has shown activation of the CD40-CD40L system and elevated level of P-selectin in women with pre-eclampsia - whether mild or severe types - compared with normal pregnant women. This may indicate an exaggerated activation of platelets and endothelial cells in the disorder which could be used as early markers for detecting pre-eclampsia. Using of such markers may be essential for developing better prediction polices influencing patient treatment decision forward and improving patient outcome for both babies and mothers suffering from pre-eclampsia.

\section{REFERENCES}

1. Hogan MC, Foreman KJ, and Naghavi M. Maternal mortality for 181 countries, 1980-2008: a systematic analysis of progress towards Millennium Development Goal 5. The Lancet 2010; 375: 1609-23.

2. LaMarca B, Cornelius D, and Wallace K. Elucidating immune mechanisms causing hypertension during pregnancy. Physiol 2013; 28: 225233.

3. WHO (2005): Make every mother and child count, in the world health report, World Health Organization, Geneva, Switzerland.

4. Xia Y, and Kellems R (2009): Is preeclampsia an autoimmune disease? Clin Immunol, 133: 1101-3.

5. Wu CF, Huang F, Sui R, and Sun J. Preeclampsia serum upregulates CD40/CD40L expression and induces apoptosis in human umbilical cord endothelial cells. Reprod Biol Endocrinol 2012; 10: 28.

6. Berghaus G, Kroczek RA: CD40 ligand on activated platelets triggers an inflammatory reaction of endothelial cells. Nature 391: 591-4.

7. Schonbeck U, Libby P (2001): The CD40/CD154 receptor/ligand dyad. Cell Mol Life Sci 2001; 58: 4-43.

8. Henn V, Steinbach S, Buchner K, Presek P, Kroczek RA. The inflammatory action of CD40 ligand (CD 154) expressed on activated human platelets is temporally limited by coexpressed CD40. Blood 2001; 98: 1047-54.

9. Mach F, Schonbeck U, Bonnefoy IY, Pober JS, Libby P. Activation of monocyte/macrophage functions related to acute atheroma complication by ligation of CD40: induction of collagenase, stromelysin, and tissue factor. Circulation 1997; 96: 396-9.

10. Fijnheer R, Frijns CJ, Korteweg J. The origin of P-selectin as a circulating plasma protein. Thromb Haemost 1997; 77: 1081-85.

11. Uszyński M, Uszyński W, Zekanowska E. P-selectin in placenta and gestational myometrium: its measurements and hypothetical role in haemostasis of placenta bed after labor. J Perinat Med 2008; 36: 213-16.

12. Wasiluk A. Markers of platelets activation CD 62P and soluble P-selectin in healthy term neonates. J Perinat Med 2004; 32: 514-5.

13. Burrows TD, King A, Loke YW. Expression of adhesion molecules by endovascular trophoblast and decidual endothelial cells: implications for vascular invasion during implantation. Placenta 1994; 15: 21-33.
14. Dunlop LC, Skinner MP, Bendall LJ, Favaloro EJ, Castaldi PA, Gorman JJ. Characterization of GMP-140 (P-selectin) as a circulating plasma protein. J Exp Med 1992; 175: 1147-50.

15. André P. P-selectin in haemostasis. Br J Haematol 2004; 126: 298-306.

16. Roberts JM, Taylor RN, Musci TJ, Rodgers GM, Hubel CA, McLaughlin MK. Preeclampsia: an endothelial cell disorder. Am J Obstet Gynecol 1989; 161: 1200-4.

17. Bar J, Ben-haroush A, Lahav J, Sullivan M. Interaction between platelets and cytokines- a possible role in the pathogenesis of preeclampsia. Vasc DisPrev 2004; 1: 101-7.

18. Henn V, Slupsky JR, Gräfe M, Anagnostopoulos I, Förster R, and MüllerBerghaus G. CD40 ligand on activated platelets triggers an inflammatory reaction of endothelial cells. Nature 1998; 391: 591-4.

19. Yoneyama Y, Suzuki S, Sawa R,Otsudo Y, Power GG, Araki T. Plasma adenosine levels and $\mathrm{P}$-selectin expression on platelets in preeclampsia. Obstet Gynecol 2001; 97: 366-70.

20. Halim A, Kanayama N, El Maradny E, Nakashima A, Bhuiyan AB, Khatun S, Terao T. Plasma P selectin (GMP-140) and glycocalicin are elevated in Preeclampsia and eclampsia: their significances. Am J Obstet Gynecol 1996; 174: 272-77.

21. Chaiworapongsa T, Romero R, Yoshimatsu J, Espinoza J, Kim YM, Park $\mathrm{K}$ et al. Soluble adhesion molecule profile in normal pregnancy and preeclampsia. J Matern Fetal and Neonatal Med 2002; 12: 19-27.

22. Bosio PM, Cannon S, McKenna PJ, O’Herlihy C, Conroy R, Brady H. Plasma P-selectin is elevated in the first trimester in women who subsequently develop preeclampsia. Br J Obstet Gynaecol 2001; 108: 709-15.

23. Karalis I, Nadar SK, Al Yemeni E. Platelet activation in pregnancy-induced hypertension. Thromb Res 2005; 116: 377-83.

24. Heyl W, Handt S, Reister F, Gehlen J, Mittermayer C, Rath W. The role of soluble adhesion molecules in evaluating endothelial cell activation in preeclampsia. Am Obstet Gynecol 1999; 180: 68-72.

25. Laskowska M, Laskowska K, and JOleszczuk J. Elevated maternal serum $\mathrm{sP}$-selectin levels in preeclamptic pregnancies with and without intrauterine fetal growth restriction, but not in normotensive pregnancies complicated by isolated IUGR. Med Sci Monit 2013; 19: 118-24.

26. Melter M, Reinders ME, Sho M, Pal S, Geehan C, Denton MD et al. Ligation of CD40 induces the expression of vascular endothelial growth factor by endothelial cells and monocytes and promotes angiogenesis in vivo. Blood 2000, 96: 3801-8

27. Garlichs CD, John S, Schmeisser A, Eskafi S, Stumpf C, Karl M et al. Upregulation of CD40 and CD40 ligand (CD154) in patients with moderate hypercholesterolemia. Circulation 2001; 104: 2395-400.

28. Ustun Y, Engin-Ustan Y, Kamaci M. Association of fibrinogen and Creactive protein with severity of preeclampsia. Eur J Obstes Gynaecol Reprod Bio 2005; 121: 154-8

29. Freedman JE, Loscalzo J. Platelet-monocyte aggregates: bridging: thrombosis and inflammation .Circulation 2002; 105: 2130-2.

30. Mellembakken, JR, Solum, N O, Ueland, T, Videm V, and Aukrust P. Increased concentrations of soluble CD40 ligand, RANTES and GRO-alpha in preeclampsia-possible role of platelet activation. Thromb.Haemost 2001; 86: 1272-76.

31. Oron G, Ben-Haroush A, Hod M, Orvieto R, and Bar J. Serum-soluble CD40 ligand in normal pregnancy and in preeclampsia. Obstet Gynecol 2006; 107: 896-900.

32. Darmochwal-Kolarz D, Kolarz B, Surdacka A, Rolinski J, LeszczynskaGorzelak B, Oleszczuk J. The expression and concentration of CD40 ligand in normal pregnancy and pre-eclampsia. J Reprod Immunol 2009; 79: $215-9$.

33. Lukanov T, Bojinova S, Emin A, Veleva G, Popova V, and Konova E. Upregulation of the CD40-CD40 ligand system in pre-eclampsia. Int $\mathrm{J}$ Gynecol Obstetrics 2009; 105: 257-60.

34. Lukanov TH, Bojinova SI, Popova VS, Emin AL, Veleva GL, Gecheva SP, Konova EI. Flow cytometric investigation of CD40-CD40 ligand system in preeclampsia and normal pregnancy. Clin Appl Thromb Hemost 2010; 16: 306-12.

35. Azzam HA, Abousamra NK, Goda H, El-Shouky R and El-Gilany A. The expression and concentration of CD40 ligand in normal pregnancy, preeclampsia, and hemolytic anemia, elevated liver enzymes and low 
platelet count (HELLP) syndrome. Blood Coagulation and Fibrinolysis 2013; 24: 71-5.

36. Laskowska M, Laskowska K, Leszczyn' ska-Gorzelak B, Oleszczuk J (2007): sCD40 ligand determined in maternal and umbilical cord blood in pregnancies complicated by preeclampsia with and without intrauterine growthretardation. Gynecol Obstet Invest; 64: 8-13. 